Article

\title{
Simulated Biomass, Climate Change Impacts, and Nitrogen Management to Achieve Switchgrass Biofuel Production at Diverse Sites in U.S.
}

\author{
Sumin Kim ${ }^{1, * \mathbb{C}}$, Sojung Kim ${ }^{2}$, Jaepil $\mathrm{Cho}^{3}$, Seonggyu Park ${ }^{4}$, Fernando Xavier Jarrín Perez ${ }^{5}$ and \\ James R. Kiniry ${ }^{6}$ \\ 1 Oak Ridge Institute for Science and Education, Temple, TX 76502, USA \\ 2 Department of Engineering and Technology, Texas A\&M University-Commerce, Commerce, TX 75429, USA; \\ sojung.kim@tamuc.edu \\ 3 Convergence Center for Watershed Management, IWMI, Suwon-si, Gyeonggi-do 16489, Korea; \\ jpcho89@gmail.com \\ 4 Blackland Research \& Extension Center, Texas A\&M AgriLife, Temple, TX 76502, USA; \\ Seonggyu.park@brc.tamus.edu \\ 5 Department of Biological and Agricultural Engineering, Texas A\&M University, College Station, TX 77842, \\ USA; fjarrin82@gmail.com \\ 6 USDA-ARS, Grassland Soil and Water Research Laboratory, Temple, TX 76502, USA; jim.kiniry@usda.gov \\ * Correspondence: sumin.kim@usda.gov; Tel.: +1-254-770-6505
}

Received: 28 January 2020; Accepted: 30 March 2020; Published: 2 April 2020

\begin{abstract}
Switchgrass (Panicum virgatum L.) is a $\mathrm{C}_{4}$, warm season, perennial native grass that has been strongly recommended as an ideal biofuel feedstock. Accurate forecasting of switchgrass yield across a geographically diverse region and under future climate conditions is essential for determining realistic future ethanol production from switchgrass. This study compiled a switchgrass database through reviewing the existing literature from field trials across the U.S. Using observed switchgrass data, a process-based model (ALMANAC) was developed. The ALMANAC simulation results showed that crop management had more effect on yield than location. The ALMANAC model consists of functional relationships that provide a better understanding of interactions among plant physiological processes and environmental factors (water, soil, climate, and nutrients) giving realistic predictions in different climate conditions. This model was used to quantify the impacts of climate change on switchgrass yields. Simulated lowland switchgrass would have more yield increases between Illinois and Ohio in future (2021-2050) under both Representative Concentration Pathway (RCP) 4.5 and 8.5 pathways with low $\mathrm{N}$ fertilizer inputs than high $\mathrm{N}$ fertilizer inputs. There was no significant effect of climate variability on upland simulated yields, which means that $\mathrm{N}$ fertilization is a key factor in controlling upland switchgrass yields under future climate conditions.
\end{abstract}

Keywords: biofuel feedstock; perennial grass; climate change; nitrogen fertilization

\section{Introduction}

In $2015,80 \%$ of the United States' total primary energy consumption was delivered from petroleum, natural gas, and coal, making the U.S. the second largest energy consumer in the world (after China) [1]. Over the last few decades, biofuel has been strongly recommended as an alternative renewable energy source to fossil-derived fuels [2,3]. Biofuels can play a critical role in reducing the emissions of greenhouse gases, especially in the transportation sector [4]. In the U.S., the transportation sector accounted for $27 \%$ of carbon dioxide emission in 2015 , the second largest emission source after electricity (29\%) [5]. The Energy Independence and Security Act (EISA) of 2007 mandated the use of 136 billion 
liters (or 36 billion gallons) of biofuels by 2022, which will help cut U.S. oil imports and boost the use of renewable fuels [6]. Two types of biofuels, ethanol and biodiesels, have been blended with petroleum fuels (gasoline and diesel fuels). More than $95 \%$ of ethanol-blended fuels were used in motor vehicles with gasoline engines in 2015 [7]. A large portion of the U.S. corn (Zea mays L.) crop (about $40 \%$ ) has been used for biofuel [8]. Corn ethanol production increased from 6.1 billion liters in 2000 to over 53 billion liters in 2014 [9]. According to The Statistics Portal [10], the U.S. produces the most biofuels (3.6 million metric tons of oil equivalent) in the world in 2016, accounting for $41 \%$ of global biofuel production. Despite the fact that the U.S. is the world's largest biofuel producer, based on the U.S. Energy Information Administration [1], only 4.6\% of total U.S. energy consumption was produced from biomass energy sources. This is still a small fraction of the total fuel consumed and will not noticeably reduce carbon dioxide emission.

Corn ethanol production has reached the U.S. Environmental Protection Agency (EPA) corn ethanol mandate threshold because corn is also needed for food and feed supplies [11]. Corn and other conventional biofuel productions have been capped at 56.8 billion liters (or 15 billion gallons) since 2017 [12]. This means the remaining 79.5 billion liters (or 21 billion gallons) of biofuels must be delivered from advanced biofuels that are made from feedstocks other than starch, sugar, or lipids [13]. Lignocellulosic biomass resources, otherwise known as second generation biomass feedstocks, represent promising feedstocks for biofuel (ethanol and biodiesel) production in the U.S.

The United States Department of Energy (DOE) has recommended switchgrass (Panicum virgatum L.) as a viable perennial herbaceous feedstock for cellulosic biofuel production. Switchgrass bioenergy research has been ongoing since 1990 at several science and education research institutions. Many genetic and agronomic studies on switchgrass have been conducted in the Midwest and Great Plains in the U.S., which have increased our understanding of the wide geographic adaptation of switchgrass cultivars, production practices, and environmental benefits [13-15]. Many studies have proved that switchgrass can produce a relatively high, reliable yield across a wide geographical range with low water and nutrient inputs [16]. Moreover, this species has high tolerances to multiple abiotic stresses, which makes it capable of maintaining high productivity on marginal soils unsuitable for traditional agricultural crops [17]. For these reasons, switchgrass has been given high research priority by many research institutions [16]. Despite the fact that a number of research reviews suggest that switchgrass represents a more viable option for sustainable biofuel production in the long-term than conventional biofuels $[15,18]$, no switchgrass cultivar is currently commercially used for biofuel production in the U.S. $[19,20]$.

The major reason that prevents switchgrass production at a commercial scale is that switchgrass cannot compete with the conventional biofuel feedstock at current market prices. Switchgrass biofuel plants tend to have greater ethanol processing costs than corn ethanol plants. Ethanol processing costs include field management (e.g., establishment, production, and harvest) [21], lignocellulose conversion to ethanol using current technology [13], and transportation (e.g., delivery of biomass collected from widely dispersed locations) [22]. These high operational costs increase the risk of adoption of switchgrass by farmers and make switchgrass unprofitable unless there are appropriate government subsidies supporting advanced biofuel production. Since 1974, the federal government has supported the development of the ethanol industry with government subsidies (e.g., tax credits, grants, and import tariff) and mandates [23]. These government supports have increased corn ethanol production and made it economically viable [24]. However, cellulosic ethanol production has fallen far short of the mandated volume [23] due to market dynamics (e.g., gasoline price volatility) and failures to achieve sustained production of cellulosic biofuel in facilities [25]. This shortfall will lead to repeated waivers of the mandated volume of cellulosic ethanol production, resulting in increasing uncertainty about the future policy for advanced biofuels [26].

Accurate forecasting of switchgrass yield across a geographically diverse region is a critical step for determining a realistic future cellulosic biofuel production target. Switchgrass production is clearly influenced both by climate and soil nutrient availability. Reichmann et al. [27] analyzed switchgrass 
yield response to nitrogen $(\mathrm{N})$ rates from 48 different switchgrass yield trials and reported that most findings of the field studies have consistently shown switchgrass yield increases from increasing $\mathrm{N}$ fertilizer application when averaged across locations and years. They also found switchgrass responded significantly to precipitation at zero or low $\mathrm{N}$ rates. These results revealed that switchgrass yield can vary within the same crop management strategies depending on climate and soil nutrients. Long-term field studies can give more accurate switchgrass yield estimation by properly accounting for the movement of $\mathrm{N}$ between soils and plants in different weather conditions. Despite the fact that the long-term field studies are more likely to reflect realistic switchgrass production estimates, such long-term switchgrass yield studies are uncommon because they require long-term commitment, funding, and dedicated study areas. Thus, plant simulation models have been developed to predict the long-term switchgrass yield and biomass production in response to different management systems and environments [28-32].

Simulation models of agricultural system are effective tools that can be used to estimate yield potential as a function of climate and soil conditions as well as crop management. Model simulations can be conducted with sufficient detail in space and time to quantify long-term changes in soil carbon, nutrients $(\mathrm{N}$ and $\mathrm{P})$ cycling, water resources, and plant production across diverse environmental conditions. To use models of agriculture systems, calibration and subsequent validations should be performed [33]. To calibrate a model, high quality datasets (e.g., weather, soil, and cropping system) are required. A calibrated model should be validated with independent field data. The ALMANAC (Agricultural Land Management Alternatives with Numerical Assessment Criteria) model is a field-scale agricultural vegetation model [34]. This model simulates plant growth, water balance, erosion, soil organic carbon, and nutrients (N and P) cycling at a daily time step. Simulations are subjected to various management strategies [35]. ALMANAC predicts growth and biomass of switchgrass and has been validated against field data for multiple sites across the southern U.S. [36,37]. Future application of this model with switchgrass will benefit from its improved simulation of switchgrass production for biofuels in diverse environments. Behrman et al. [29] simulated switchgrass yields across the central and eastern U.S. with different climate change scenarios. However, in this study, a measured field data set collected in limited locations were used for model validation, which may increase the uncertainty in yield predictions over large areas. A more extensive study with more cultivars, years and additional location is needed to test how accurately the model simulates long-term yield dynamics of switchgrass across a wider range of soil types, temperature zones, and rainfall zones.

To improve model performance, large amounts of switchgrass productivity data from multiple regions including North Central, South Central, South East, North East regions in U.S. were collected and used to first calibrate and then validate ALMANAC's simulated yields in this study. This will increase confidence of the use of ALMANAC for yield forecasting with long-term changes in environmental factors (e.g., climate, water source, and soil) in various locations. Based on the collected yield data, the major factors influencing yield variability of switchgrass in U.S. will be analyzed using an additive regression model (ARM). The ARM applies functions fitted to data without considering the physiological processes involved in plant growth and morphogenesis and uses key variables that significantly affect yield of switchgrass as inputs. The ARM, based on the data collected over a wide geographic area under diverse management practices, was used to analyze past switchgrass growth data and to describe the yield responses of switchgrass lowland and upland cultivars to environmental covariates and management practices. The significant factor for switchgrass yield will be used for ALMANAC simulation analysis. The objectives of the study are the following: to develop realistic switchgrass yield estimates for diverse regions of the U.S.; to project future scenarios; and to explore the diversity of yield responses of two switchgrass ecotypes to climate change and different fertilizer applications. Each of these objectives was evaluated under three climate scenarios (base climate in 1976-2005 and two future climate scenarios using a representative concentration pathway (RCP 4.5 and RCP 8.5). 


\section{Materials and Methods}

\subsection{Data Collection}

In this study, two major switchgrass ecotypes, "Upland" and "Lowland," were parameterized using extensive measured field data. The upland and lowland ecotypes were differentiated by morphological and genetic variations [38-40]. The lowland ecotype generally has fewer and larger tillers, erect growth, a compact crown, and blue-green waxy leaves, compared to upland ecotype [38,40]. Lowland ecotype is well adapted in wetter conditions, while upland ecotype is commonly found in drier soils [40]. Upland ecotype has higher cold tolerance than lowland ecotype [41,42]. Moreover, Zhang et al. [39] found that genetic variation in cytoplasm was highly correlated with the divergence of the ecotypes.

The experimental datasets used in this study were compiled from numerous peer-reviewed studies that reported switchgrass productivity in experiments conducted in stands $\geq 2$ years old growing in plots (Table S1, Figure 1). Only biomass yields harvested once per year, either at the end of the growing season, after first killing frost, or in early spring, were used for the analysis. In this study, a total of 66 different locations from 32 peer-reviewed publications were analyzed and included 45 switchgrass cultivars (16 lowland cultivars and 29 upland cultivars). Fertilizer rates ranged from 0 to $896 \mathrm{~kg} \mathrm{~N} \mathrm{ha}^{-1} \mathrm{yr}^{-1}$. The study locations, switchgrass ecotypes, cultivars, maximum and minimum dry yields of cultivars within each state, and references are listed in Table S1. Based on the database, yield patterns for each cultivar and each ecotype were analyzed. Weather data included total precipitation, minimum temperature, and maximum temperature for the study sites for the years of the study collected from National Oceanic and Atmospheric Administration (NOAA) [43]. Soil information including percentage of clay, silt, and sand in $100 \mathrm{~cm}$ soil depth was downloaded from the Natural Resources Conservation Service, United States Department of Agriculture, Soil Survey Geographic Database (USDA NRCS SSURGO database) [44]. Values of measured leaf area index (LAI, total one-sided area of leaf tissue per unit ground surface) for each switchgrass cultivar were collected from seven peer-reviewed studies conducted in latitudes from $31^{\circ} \mathrm{N}$ to $45^{\circ} \mathrm{N}$.

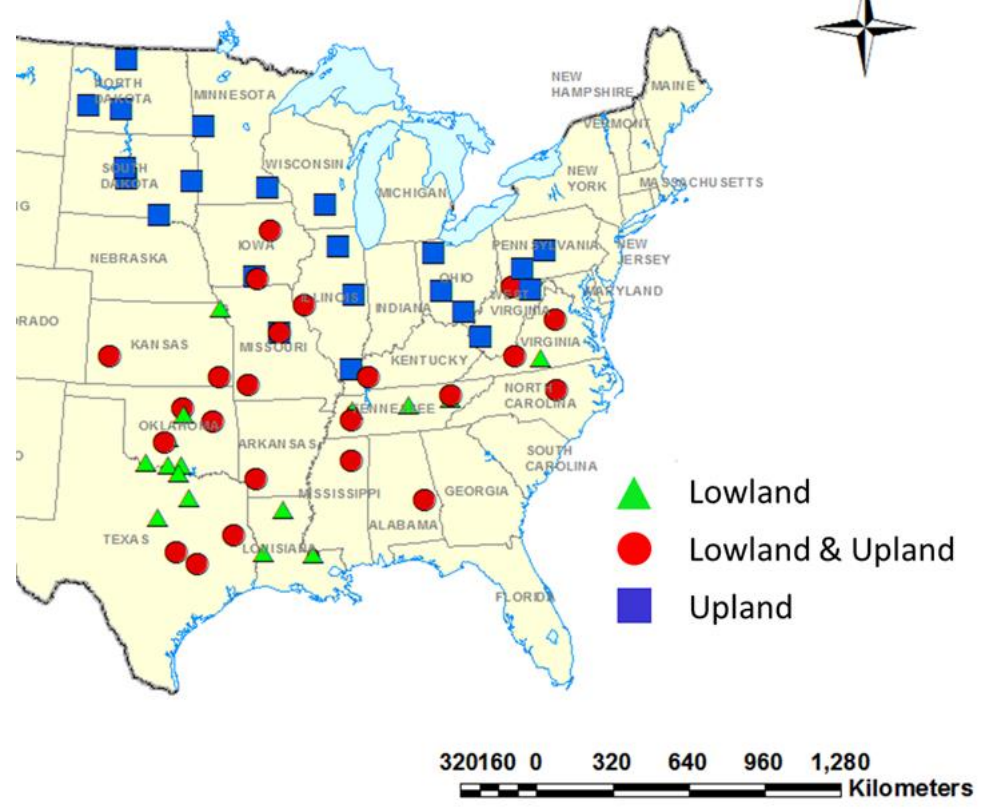

Figure 1. Locations with switchgrass biomass yields across the United States reported in literature reviews. Green triangle, red circle, and blue square indicate study locations where only switchgrass lowland cultivars, both switchgrass lowland and upland, and only switchgrass upland cultivars were conducted, respectively. 


\subsection{Analysis of Factors Determining Switchgrass Yield}

Switchgrass growth and development are affected by numerous factors, including temperature [45], rainfall [46], fertilizer inputs [47], and field location (e.g., soil type and latitude) [37,48]. To determine which variable explains most of the variation in switchgrass yields, in first phase, correlations and the importance of 14 variables for yield in switchgrass were analyzed. The correlation scores for the 14 variables were switchgrass ecotype $(-0.09)$; latitude $(-0.40)$; longitude $(0.37)$; soil type $(0.06)$; components of sand (-0.05), silt (-0.05), and clay (0.18); Growing Degree Days (GDD) (0.29); total precipitation from April to September (0.36); average precipitation (0.36); minimum temperature (0.37); maximum temperature (0.22); average temperature (0.31); and $\mathrm{N}$ fertilizer rate (0.35). GDD is the accumulated growing degree days or heat units throughout growing season (April 1st-July 15th) at each study location. Variables with absolute correlation scores less than 0.3 have been removed so that only 8 variables were chosen at the first phase. At the second phase, since a high correlation between predictor variables decreases the precision of the estimated regression coefficient, the highly correlated predictor variables were removed from the model. To be more specific, minimum temperature is correlated with other selected factors, such as average temperature (0.96) and maximum temperature (0.86). Among the three factors, the minimum temperature that has the highest correlation score with the switchgrass crop yield is selected. Similarly, total precipitation is selected and its correlated factor (i.e., average precipitation (0.99)) was removed.

Five predictor variables, including $\mathrm{N}$ fertilizer rate $\left(X_{1}\right)$, latitude $\left(X_{2}\right)$, longitude $\left(X_{3}\right)$, minimum temperature $\left(X_{4}\right)$, and total precipitation $\left(X_{5}\right)$ from April to September, were used to establish the switchgrass yield estimation additive regression model (ARM). The values of these variables were standardized prior to regression (i.e., data point subtracted from the mean and divided by the standard deviation of the distribution).

ARM is expressed as follows [49]:

$$
Y=\alpha+f_{1}\left(X_{1}\right)+f_{2}\left(X_{2}\right)+f_{3}\left(X_{3}\right)+f_{4}\left(X_{4}\right)+f_{5}\left(X_{5}\right)+\varepsilon, \varepsilon \sim N\left(0, \sum_{j=1}^{5} \sigma_{j}^{2}\right)
$$

where $f_{j}\left(X_{j}\right)=\beta_{j 1}\left(X_{j}\right)+\beta_{j 2}\left(X_{j}^{2}\right)+\cdots+\beta_{j L}\left(X_{j}^{L}\right)$ and $\alpha=\sum_{j=1}^{5} \beta_{j 0}$.

In Equation (1), $Y$ is the response based on the five predictors variables and $\beta_{j 1}$ is the weight for the $j$ th predictor with $l$ th order, where $l=1,2, \ldots, L$. The weight in each term represents significance of each variable on determining a value of $Y$ (switchgrass yield). Error term $\varepsilon$ follows the normal distribution with mean zero and variance $\sum_{j=1}^{5} \sigma_{j}^{2}$. Thus, the ARM can be illustrated as the multivariate normal distribution shown below:

$$
Y \sim N\left(\sum_{j=1}^{5} \mathbf{X}_{j} \boldsymbol{\beta}_{j}, \sum_{j=1}^{5} \sigma_{j}^{2}\right)
$$

In Equation (2), $\mathbf{X}_{j}=\left[X_{j}^{1}, X_{j}^{2}, \ldots, X_{j}^{L}\right]$ and $\boldsymbol{\beta}_{j}=\left[\beta_{j 1}, \beta_{j 2}, \ldots, \beta_{j L}\right]$. Once the maximum order $L$ is given, the maximum likelihood approach can be used to find the weight $\beta_{j l}$, where $l=1, \ldots, L$.

However, since $L$ is unknown, the structure learning approach with the 10-fold cross validation $(C V)$ is utilized. In other words, the CV test will find a structure of $f_{j}\left(X_{j}\right)$ in Equation (1) with the minimum LOOCV error [50].

$$
L_{i}^{C V}=\frac{1}{N}\left(\mathbf{Y}_{i}-\hat{\mathbf{Y}}_{i}\right)^{T}\left(\mathbf{Y}_{i}-\hat{\mathbf{Y}}_{i}\right)
$$

In Equation (3), $\mathbf{Y}_{i}$ is a vector involving observed values of $Y$ in test set $i$ and $\hat{\mathbf{Y}}_{i}$ is a vector involving estimated values of $\mathbf{Y}$ via Equation (1). 


\subsection{ALMANAC Model Simulation of Development}

The ALMANAC model is a field-based process-level simulator that accurately simulates growth, development, and yield of plants as influenced by environmental conditions and management. In simulation, to determine the effects of environmental condition on yields, switchgrass plants were produced only in rainfed areas. These are specified for the model as input data. Thus, to improve the stability and accuracy of plant growth simulation, high-quality input data for weather, soil, and management are required [51]. For calibrating ALMANAC, three research studies were selected from the total of 45 studies. These studies measured initial soil characteristics (e.g., nutrients, organic matter, $\mathrm{N}$ content, etc.) in the fields. The detailed soil information, location, and information on previous land use are listed in Table S2. Management for each study is below.

Study 1: The field study was conducted in 2008 and 2009 at three locations (Northwest, Jackson, and Western) in Ohio. One upland switchgrass cultivar (cave-in-rock) was established in 2004 at $11.2 \mathrm{~kg} \mathrm{ha}^{-1}$. Four rates of $\mathrm{N}$ fertilizer $\left(0,50,100\right.$, and $\left.200 \mathrm{~kg} \mathrm{~N} \mathrm{ha}^{-1}\right)$ were applied between May and July in both years. Ammonium nitrate was used as fertilizer in 2008, and urea was applied in 2009. Switchgrass was harvested in October in 2008 and November in 2009. More detailed information is available in Jung and Lal [52].

Study 2: Field research was conducted in 2007 and 2008 at Manhattan, Kansas and Troy, Kansas. Lowland switchgrass cultivar (Kanlow) was planted in 2007 into soybean residue at $4.0 \mathrm{~kg}$ seeds ha ${ }^{-1}$. No N, P and K fertilizer were applied in 2007 , but $45 \mathrm{~kg} \mathrm{~N} \mathrm{ha}^{-1}$ was applied as urea (N-P-K, 46-0-0) in 2008. Switchgrass was harvested in November in both years. More detailed information is available in Propheter et al. [53].

Study 3: The field study was conducted in 2008-2010 at Ardmore, Oklahoma and Waurika, Oklahoma. A one-year old lowland switchgrass cultivar (Alamo) was transplanted in 2008. Each experiment was a randomized complete block design with a split-plot arrangement and four replicates. $\mathrm{N}$ fertilizer rates $\left(0\right.$ and $135 \mathrm{~kg} \mathrm{~N}^{-1}$ ) were whole plots, while $\mathrm{P}$ fertilizer rates $(0,15,30$, and $45 \mathrm{~kg} \mathrm{P}$ $\mathrm{ha}^{-1}$ ) were sub-plots. Switchgrass was harvested after first killing frost in 2008-2010 at both locations. More detailed information is available in Kering et al. [54].

Weather data used for each study location were from the nearest and most complete National Oceanic Atmospheric Administration (NOAA) station [43]. Soil data for each study location were obtained from the USDA NRCS SSURGO database [44]. Based on the published values of initial soil data (Table S2), field characteristics were initialized at the start of the run for each site.

In the ALMANAC Plant database, two separate sets of plant parameters named Lowland and Upland were created for switchgrass (Table S3). Since upland cultivars consistently flower earlier than lowland cultivars [55,56], the values of degree days from green up to senescence for upland cultivars are less than for lowland cultivars [57]. The values of degree days varied with latitude [57]. Thus, potential heat units (PHU), degree days from green up to senescence, were adjusted for each of cultivar and location. The degree-days were set to zero when new tiller growth begins to emerge from the base of the plants [29]. The PHU value for each state and ecotype was calculated as accumulated heat units; that involves averaging the maximum and minimum local temperature for each day and subtracting the baseline temperature of $12{ }^{\circ} \mathrm{C}$ [57]. Upland cultivar had $1200 \mathrm{PHU}$ for the three locations in $\mathrm{OH}$. Lowland cultivar had 2000 PHU for two locations in KS and 2500 PHU for two locations in OK.

The value of the fraction of seasonal PHU at anthesis (DLAI) was 0.7 for both upland and lowland cultivars. In simulation, after switchgrass approached its maximum yield, the leaf area index started to decrease until harvest. We assumed that the measured yields were reported as maximum yields within the growing season for the study. Thus, in simulation, the potential maximum yields remained unchanged until harvest. The maximum potential leaf area index (DMLA) parameter for lowland and upland was firstly assigned by state based on leaf area index taken from previous studies [58-63]. Lowland cultivars have consistently greater values of leaf area index (LAI) than upland cultivars in southern part of U.S. The highest values of LAI were obtained in both southern and northern part of U.S. Unlike lowland cultivars, the lowest LAI for upland was obtained in southern part of U.S. 
Then, the DMLA parameters for lowland and upland were determined by comparing the ALMANAC simulation results with measured yields. The value for DMLA for lowland was determined to be 12 for all simulated locations. The DMLA for upland cultivars in $26^{\circ}-32^{\circ} \mathrm{N}$ latitude range was determined to be 2.5 , while the LAI in $33^{\circ}-48^{\circ} \mathrm{N}$ latitude range was determined to be 6.0 .

Based on the measured plant height values [55,56], the values of maximum crop height (HMX), for lowland and upland cultivars, were determined. Additionally, the values of HMX for lowland and upland cultivars were 2.5 and $1.3 \mathrm{~m}$, respectively. Other switchgrass parameters were derived from previous studies [36,37].

For model validation, the calibrated ALMANAC model simulated switchgrass biomass across 59 additional sites from previous studies (Figure 1). For these other sites, lowland and upland cultivars had PHU 3000 and 2500 in $30^{\circ}-32^{\circ} \mathrm{N}$ latitude range, respectively; PHU 2500 and 2000 in $32^{\circ}-37^{\circ} \mathrm{N}$ latitude range, respectively; PHU 2000 and 1500 in $37^{\circ}-38.5^{\circ} \mathrm{N}$ latitude range, respectively; PHU 1800 and 1500 in $38.5^{\circ}-39^{\circ} \mathrm{N}$ latitude range, respectively; PHU 1600 and 1200 in $39^{\circ}-41^{\circ} \mathrm{N}$ latitude range, respectively; PHU 1400 and 1100 in $42^{\circ}-43.9^{\circ} \mathrm{N}$ latitude range, respectively. Upland cultivars had PHU 900 in $44-48^{\circ} \mathrm{N}$ latitude range. The same managements (e.g., planting, fertilizer, and harvesting) were used in the model as reported for each field study. Due to lack of information on soil characteristics in the publications, soil initial nutrient contents $(\mathrm{N}$ and $\mathrm{P}$ ) were calibrated for most sites using published biomass data.

Simulated biomass values were compared with measured values that came from field measurements of Studies 1-3. The measured yields that were averaged across cultivars within each ecotype from each study location were also compared with simulated yields of lowland and upland switchgrass cultivars across other 59 study sites. The root-mean square error (RMSE, Equation (4)), RMSE-observations standard deviation ratio (RSR, Equation (5)), Nash-Sutcliffe efficiency (NSE, Equation (6)), and percent bias (PBIAS, Equation (7)) were calculated to quantify the model adequacy.

$$
\begin{gathered}
\text { RMSE }=\sqrt{\frac{\sum_{i=1}^{n}\left(O_{i}-S_{i}\right)^{2}}{n}} \\
R S R=\frac{\sqrt{\sum_{i=1}^{n}\left(O_{i}-S_{i}\right)^{2}}}{\sqrt{\left(O_{i}-O_{\text {mean }}\right)^{2}}} \\
N S E=1-\left[\frac{\sum_{i=1}^{n}\left(O_{i}-S_{i}\right)^{2}}{\sum_{i=1}^{n}\left(O_{i}-O_{\text {mean }}\right)^{2}}\right] \\
\text { PBIAS }=\left[\frac{\sum_{i=1}^{n}\left(O_{i}-S_{i}\right) \times 100}{\sum_{i=1}^{n} O_{i}}\right]
\end{gathered}
$$

where $i$ is the $i$ th observation, $n$ is the total number of observations, $S_{i}$ is the $i$ th simulated value, $O_{i}$ is ith observed value, and $O_{\text {mean }}$ is the mean of observed data. Additionally, Pearson's correlation coefficient of determination $\left(\mathrm{R}^{2}\right)$ was estimated using Proc REG in Statistical Analysis Software version 9.3 (SAS 9.3, SAS Institute Inc., Cary, North Carolina, U.S.).

\subsection{Climate Change Projection}

For the future climate projection, APCC Integrated Modeling Solution (AIMS) was used to downscale climate change scenario information using eight global circulation models (GCMs) from CMIP5 (Coupled Model Intercomparison Project Phases) as provided in Table 1. 
Table 1. Global circulation models (GCMs) considered in this study.

\begin{tabular}{ccc}
\hline Model Name & Modeling Center (or Group) & Reference \\
\hline CCSM4 & Climate and Global Dynamics Laboratory & Gent et al. [64] \\
CESM1-CAM5 & National Center for Atmospheric Research & Meehl et al. [65] \\
CMCC-CMS & Centro Euro-Mediterraneo per I Cambiamenti Climatici & Fogli et al. [66] \\
GFDL-ESM2G & Princeton University Forrestal Campus & Dunne et al. [67] \\
HADGEM2-AO & Korean National Institute of Metrological Research & Baek et al. [68] \\
& Atmosphere and Ocean Research Institute (The & \\
MIROC5 & University of Tokyo), National Institute for & Watanabe et al. [69] \\
& Environmental Studies, and Japan Agency for & \\
MPI-ESM-LR & Marine-Earth Science and Technology & Giogetta et al. [70] \\
MRI-CGM3 & Max Planck Institute for Meteorology & Kitoh et al. [71] \\
\hline
\end{tabular}

Two core representative concentration pathways (RCP) scenarios including RCP4.5 and RCP8.5 were analyzed. The RCPs represents possible changes in future greenhouse gas (GHG) concentrations. Concentrations in RCP 4.5 peak around 2040 and decline, while concentrations in RCP 8.5 continue to increase throughout the 21st century. As a result, the RCP4.5 scenario projects global temperature increases of $1.1-2.6{ }^{\circ} \mathrm{C}$ in the future, while the RCP8.5 scenario leads to a temperature increase of $2-3{ }^{\circ} \mathrm{C}$ by the end of the 21st century [30]. The selected GCMs were bias-corrected and downscaled for historical (1976-2005) and the future periods (2021-2050), by using simple quantile mapping methods based on the reproducibility of minimum temperature and precipitation-amount-related extreme climate indices for the past [72]. The observed past weather data containing daily minimum and maximum temperatures and precipitation were obtained from National Oceanic and Atmospheric Administration (NOAA) [43]. Observed data for the weather station closest to each switchgrass field study site were collected as input (Figure 1).

To quantify the impact of climate change on the switchgrass yield in two different $\mathrm{N}$ managements, including N50 and N150, the outputs of climate variables from the selected eight GCMs were fed into the calibrated ALMANAC model, and the switchgrass yield was projected in future period (2021-2050). Here, the period of 1976-2005 is selected to represent the reference climate conditions. The period of 2021-2050 is selected to represent future climate conditions. According to Li et al. [73], expansion of ethanol production in the U.S. has minimal effect on changes in crop land use. Thus, it was assumed that there will be no changes in land use for the study areas in the future. Climate variables in the future, such as wind speed, relative humidity, and sunshine hours, were also assumed to be the same as the baseline period.

\section{Results and Discussion}

\subsection{Switchgrass Yield Analysis}

Lowland switchgrass cultivars produced consistently higher yields than upland cultivars (Figure 2). The mean dry yields of lowland and upland switchgrass across locations, management scenarios, cultivars, and years were $14.0 \mathrm{Mg} \mathrm{ha}^{-1}$ and $7.4 \mathrm{Mg} \mathrm{ha}^{-1}$, respectively. Switchgrass yields varied widely among locations depending on establishment time, management, soil, and climatic factors. Among the states, the highest yields of both groups of switchgrass cultivars were in Alabama, while the lowest yields were in Arkansas (Table S1). Switchgrass biomass had been fertilized with $84 \mathrm{~kg} \mathrm{ha}^{-1} \mathrm{yr}^{-1} \mathrm{~N}$ for 10 years in Alabama [74], while switchgrass had been fertilized with $134 \mathrm{~kg} \mathrm{ha}^{-1} \mathrm{yr}^{-1} \mathrm{~N}$ only for 3 years in Arkansas [41]. Among lowland switchgrass cultivars, Alamo had the highest mean value of $15.9 \mathrm{Mg} \mathrm{ha}^{-1}$ (Figure S1) and produced as high as $39.3 \mathrm{Mg} \mathrm{ha}^{-1}$ with higher $\mathrm{N}$ fertilizer inputs at Texas [75]. When rainfall was low in 1996, among lowland switchgrass cultivars, Kanlow produced the lowest yield of $1.9 \mathrm{Mg} \mathrm{ha}^{-1} \mathrm{yr}^{-1}$ with $134 \mathrm{~kg} \mathrm{ha}^{-1} \mathrm{yr}^{-1} \mathrm{~N}$ fertilizer inputs at Dallas in Texas. NL931 produced the lowest mean yield of $9.15 \mathrm{Mg} \mathrm{ha}^{-1} \mathrm{yr}^{-1}$ among other lowland cultivars (Figure S1). 
Among upland switchgrass cultivars, cave-in-rock can be produced as high as $26.1 \mathrm{Mg} \mathrm{ha}^{-1} \mathrm{yr}^{-1}$ with $200 \mathrm{~kg} \mathrm{~N}$ fertilizer inputs in 2009 at Western in Ohio [52]. However, based on 108 cave-in-rock data values, the mean yield value for this cultivar was $8.97 \mathrm{Mg} \mathrm{ha}^{-1} \mathrm{yr}^{-1}$. Carthage cultivar produced the lowest mean yield of $2.5 \mathrm{Mg} \mathrm{ha}^{-1} \mathrm{yr}^{-1}$ with no nitrogen input between 2009 and 2011 at Hobet in West Virginia [76]. Among upland cultivars that are commercially available, shelter and Caddo cultivars produced the highest mean yields near $9.7 \mathrm{Mg} \mathrm{ha}^{-1} \mathrm{yr}^{-1}$ (Figure S1).
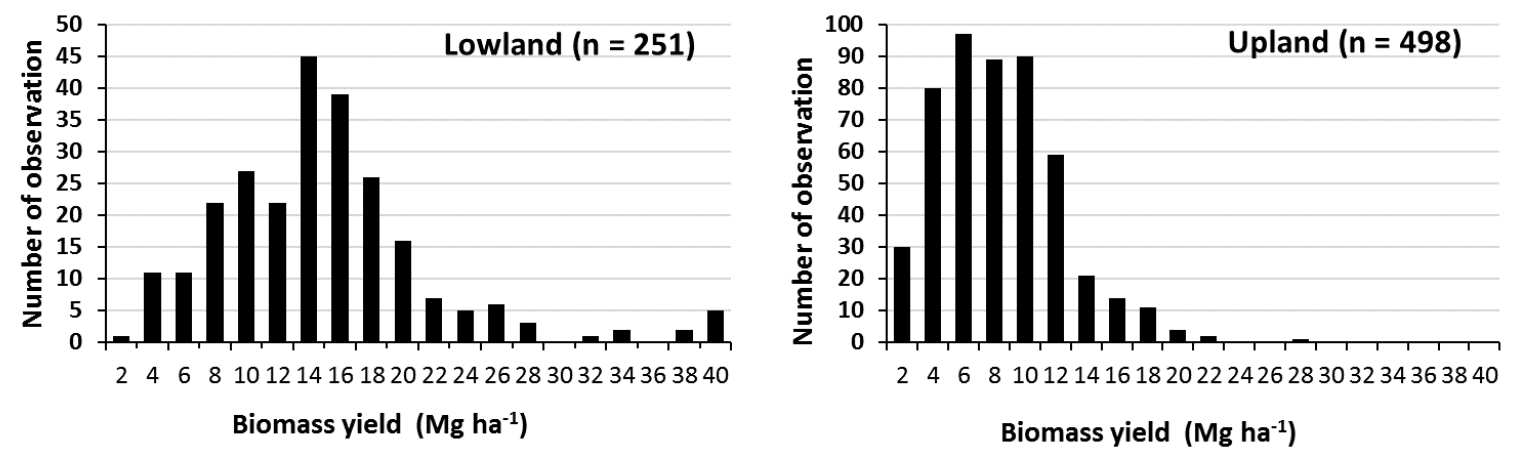

Figure 2. Frequency distribution showing biomass yields reported for upland and lowland cultivars. The number of observations analyzed for cultivars of each ecotype is shown in parentheses.

\subsection{Analysis of Factors Influencing Yield Variability of Lowland and Upland Ecotypes}

Using the latitude, longitude, climatic, and management dataset collected from total 66 study sites, ARM has been developed separately for lowland and upland cultivars. The ARM is:

For lowland cultivars,

$$
\begin{aligned}
& Y=0.054+0.496 X_{1}-0.080 X_{1}^{2}+0.354 X_{2}+0.232 X_{2}^{2}-0.073 X_{2}^{3}+0.827 X_{3} \\
& +0.424 X_{3}^{2}-0.406 X_{3}^{3}+0.263 X_{4}-0.189 X_{4}^{2}+0.006 X_{5}+\varepsilon, \varepsilon \sim N(0,0.698)
\end{aligned}
$$

For upland cultivars,

$$
\begin{aligned}
& Y=0.212+0.321 X_{1}-0.064 X_{2}+0.240 X_{2}^{2}+0.160 X_{2}^{3}-2.136 X_{3}-16.102 X_{3}^{2}-25.376 X_{3}^{3} \\
& +0.664 X_{4}-0.102 X_{4}^{2}-0.102 X_{4}^{3}-0.105 X_{5}-0.388 X_{5}^{2}+0.192 X_{5}^{3}+\varepsilon, \varepsilon \sim N(0,0.288)
\end{aligned}
$$

In Equations (8) and (9), an absolute coefficient in each term represents the significance of each variable on the potential yield estimation of switchgrass. In other words, a larger value of the absolute coefficient refers to higher correlation between a predictor variable and a response variable. In Equations (8) and (9), because longitude $X_{-3}$ has the highest total coefficients of $1.658(=0.827+0.424$ $+0.406)$ and $43.614(=2.136+16.102+25.376)$ for lowland and upland cultivars, respectively, we can intuitively understand that it is the most critical variable to determine the potential yield estimation of switchgrass.

The resulting high correlation between switchgrass biomass and longitude is interesting and perplexing. Casler et al. [77], with latitudes ranging from $94^{\circ} \mathrm{W}$ to $101^{\circ} \mathrm{W}$, also found significant differences due to longitude of their evaluation locations. In the study [77], few switchgrass cultivars (e.g., Pathfinder, Blackwell, CIR, WS98-IP) had significant linear relation to longitude of the study locations because their heading dates were changed by longitude. However, most of previous studies have reported a weak relationship among switchgrass yield and longitude [48,78-80]. This may be because most of the previous studies were carried out between $95^{\circ}$ and $100{ }^{\circ} \mathrm{W}$. Longitudes in the present study ranged from 77.97 to $102.8^{\circ} \mathrm{W}$. Looking at mean solar radiation (NOAA, 1977 NOAA, National Oceanic and Atmospheric Administration, 1993. Climatic Atlas of the United States, Asheville, North Carolina), there are no clear trends with longitude in this region in the months of April through August. However, there are definite east-west gradients in relative humidity for the 
months of June, July, and August. Likewise, there is an obvious east-west gradient in mean annual pan evaporation. It seems that switchgrass as a species favors the lower humidity, higher evaporative demand environments of the more westerly locations.

According to the Equation (8), significant factors on the yields of lowland cultivars are as follows: longitude (1.658), latitude (0.659), $\mathrm{N}$ fertilizer rate (0.576), minimum temperature (0.452), and total precipitation (0.006). The total precipitation had the least effect on the yields of lowland cultivars. This result is supported by Abdullahi et al. [81] who reported that the dry yield of upland cultivar was significantly decreased by decreasing irrigation frequency, while the irrigation regimes had a negligible impact effect on dry yield of lowland cultivar. Moreover, Sanderson and Reed [82] reported that the growth of switchgrass lowland cultivar in Central Texas did not respond to additional water. In Equation (9), the significance of predictor variables for the yields of upland cultivars is as follows: longitude (43.614), minimum temperature (0.868), total precipitation (0.685), latitude (0.463), and $\mathrm{N}$ fertilizer rate (0.031). Unlike lowland cultivars, $\mathrm{N}$ fertilizer rate had the least effect on the yields of upland cultivars, which means that upland yields are more influenced by regional adaptation, rather than $\mathrm{N}$ rate. According to Fike et al. [83], upland cultivars had lower yields in poorly drained sites and did not respond to fertilizer rate under low rainfall condition. However, upland cultivars produced higher yields and responded noticeably to $\mathrm{N}$ fertilizer rate from moderately well drained soil and under higher rainfall condition.

To evaluate the performance of ARM simulation, the ARM simulated yields were compared with the measured yields. In overall, ARM simulated switchgrass yields agreed moderately well with the measured yields across locations while showing the model failed to identify catchments with higher and lower yields for both ecotypes (Figure 3). Regression analysis for ARM simulated and measured yields of lowland and upland cultivars including all data from total 66 study sites revealed $R^{2}=0.30$ and 0.37 , respectively (Figure 3). Since ARM was developed based on the few key parameters, $R^{2}$ was relatively low. However, the simulated yields and measured yields for both lowland and upland cultivars were not significantly different (Both $p \geq 0.78$ ) (Figure 3 ).
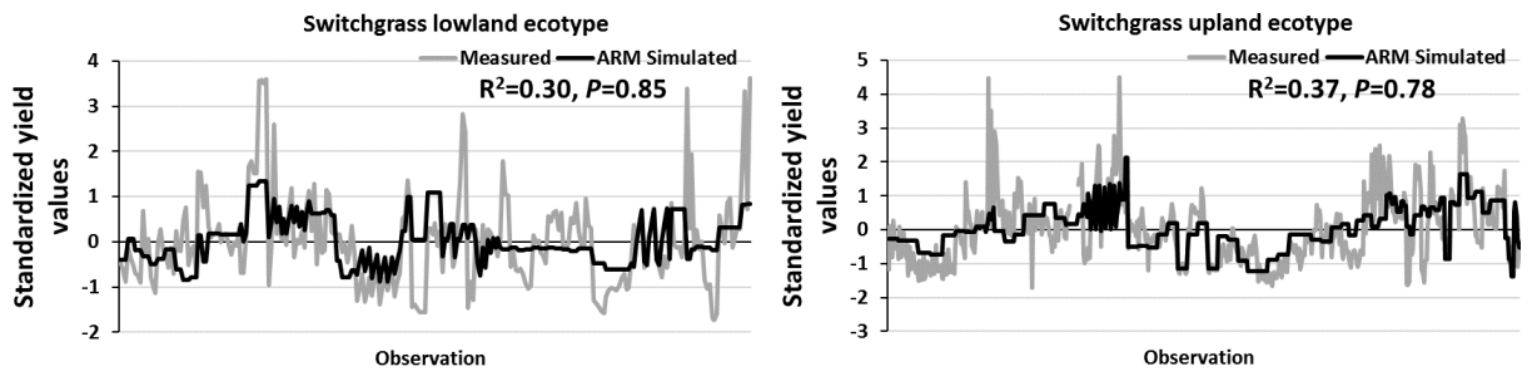

Figure 3. Relation between measured and ARM simulated yields for lowland and upland switchgrass cultivars. The grey solid line represents the measured yields, and the black solid line represents the ARM solid lines. Measured and simulated yields were statistically compared using t-test at $\alpha=0.05$.

\subsection{ALMANAC Evaluation}

The ALMANAC model was calibrated against measured data for biomass yields from Study 1-3 (Table 1). The Studies 1 and 3 were carried out on upland and lowland cultivars, applying various $\mathrm{N}$ fertilizer treatments, at multiple locations in Ohio and Oklahoma for 3-5 years (Table 2). In both studies, measured switchgrass yields increased as $\mathrm{N}$ fertilizer input increased.

The ALMANAC simulated yields, which responded to different $\mathrm{N}$ fertilizer rate applications, were compared with measured yields using $\mathrm{R}^{2}$, RMSE, RSR, NSE, and PBIAS (Table 3). As shown, the percent bias values for upland and lowland cultivars were under $10 \%$. Based on the general performance rating of Moriasi et al. [84], the simulated yields of upland and lowland cultivars in Ohio, Kansas, and Oklahoma may be evaluated as "very good." However, based on values of RSR (0.97) and NSE (0.05), upland simulated yields can be evaluated as "unsatisfactory." The model underestimated 
upland switchgrass yields at high soil organic carbon and high total N. For example, high soil organic carbon and high total $\mathrm{N}$ were observed in the Northwest site, $\mathrm{OH}$ site (Table S2). In this site, the simulated yield differences were not as great as those observed yields from 50 to $200 \mathrm{~N} \mathrm{~kg} \mathrm{ha}^{-1}$ (Table 2). At high soil organic carbon, in simulation, the optimal plant growing condition (no N stress) was likely to appear with less $\mathrm{N}$ application. This may cause failure of model to adequately simulate the yield changes at upper range of $\mathrm{N}$ input. Unlike upland simulations, lowland simulations can be estimated as "good," based on values of RSR and NSE (Table 3). The RMSEs between measured and simulated yields for upland and lowland cultivars were 3.52 and $1.44 \mathrm{Mg} \mathrm{ha}^{-1}$, respectively.

Table 2. Measured and simulated yields at different nitrogen $(\mathrm{N})$ fertilizer rates for upland and lowland cultivars at Ohio, Kansas, and Oklahoma, USA.

\begin{tabular}{|c|c|c|c|c|}
\hline Site & $\begin{array}{l}\text { Switchgrass } \\
\text { Ecotype }\end{array}$ & $\begin{array}{l}\text { Fertilizer Rate } \\
\quad \text { N kg ha }\end{array}$ & $\begin{array}{c}\text { Measured } \\
\left.\text { Yield (Mg ha }{ }^{-1}\right)\end{array}$ & $\begin{array}{c}\text { Simulated } \\
\text { Yield }\left(\mathrm{Mg} \mathrm{ha}^{-1}\right)\end{array}$ \\
\hline \multirow[t]{4}{*}{ Northwest, $\mathrm{OH}^{\mathrm{a}}$} & Upland & 0 & 10.45 & 10.38 \\
\hline & & 50 & 11.95 & 11.8 \\
\hline & & 100 & 13.45 & 12.04 \\
\hline & & 200 & 14.45 & 12.05 \\
\hline \multirow[t]{4}{*}{ Jackson, $\mathrm{OH}^{\mathrm{a}}$} & Upland & 0 & 7.2 & 8.02 \\
\hline & & 50 & 11.05 & 9.22 \\
\hline & & 100 & 11.25 & 14.22 \\
\hline & & 200 & 11.7 & 15.97 \\
\hline \multirow[t]{4}{*}{ Western, $\mathrm{OH}^{\mathrm{a}}$} & Upland & 0 & 12.8 & 8.92 \\
\hline & & 50 & 15.3 & 12.79 \\
\hline & & 100 & 15.95 & 13.38 \\
\hline & & 200 & 22.5 & 13.47 \\
\hline $\begin{array}{c}\text { Troy, } \mathrm{KS}^{\mathrm{b}} \\
\text { Manhattan, } \mathrm{KS}^{\mathrm{b}}\end{array}$ & Lowland & 0 & 6.65 & 6.58 \\
\hline \multirow[t]{2}{*}{ Ardmore, $\mathrm{OK}^{\mathrm{c}}$} & Lowland & 0 & 6.47 & 6.27 \\
\hline & & 135 & 12.97 & 13.61 \\
\hline \multirow[t]{2}{*}{ Waurika, $\mathrm{OK}^{\mathrm{c}}$} & Lowland & 0 & 9.57 & 8.57 \\
\hline & & 135 & 12.67 & 9.67 \\
\hline
\end{tabular}

${ }^{\mathrm{a}}$ Jung and Lal [52]; ${ }^{\mathrm{b}}$ Propheter et al. [53]; ${ }^{\mathrm{c}}$ Kering et al. [54].

Table 3. Measured and simulated yields and ALMANAC model calibration and validation performances based on R2, RMSE, RSR, NSE, and PBIAS. $\mathrm{R}^{2}$ is Pearson's correlation coefficient of determination; RMSE is root mean square error; RSR is RMSE-observations standard deviation ratio; NSE is Nash-Sutcliffe efficiency; and PBIAS is percent bias.

\begin{tabular}{ccccc}
\hline & \multicolumn{2}{c}{ Calibration } & \multicolumn{2}{c}{ Validation } \\
\cline { 2 - 5 } & Upland & Lowland & Upland & Lowland \\
\hline Measured yield $\left(\mathrm{Mg} \mathrm{ha}^{-1}\right)$ & 13.17 & 9.66 & 7.48 & 14.63 \\
Simulated yield $\left(\mathrm{Mg} \mathrm{ha}^{-1}\right)$ & 11.86 & 8.94 & 7.26 & 13.89 \\
$\mathrm{R}^{2}$ & 0.21 & 0.82 & 0.65 & 0.65 \\
RMSE $\left(\mathrm{Mg} \mathrm{ha}^{-1}\right)$ & 3.52 & 1.45 & 2.36 & 3.74 \\
RSR & 0.97 & 0.51 & 0.61 & 0.62 \\
NSE & 0.05 & 0.73 & 0.62 & 0.62 \\
PBIAS $(\%)$ & 9.9 & 7.5 & -2.8 & -5.1 \\
\hline
\end{tabular}

After initial calibration of the model using detailed soil characteristics from seven different sites, the developed switchgrass model simulated yields in 59 other sites to determine how well it can predict yield under various climatic conditions. Both upland and lowland simulations can be evaluated as 
"very good" because PBIAS for both ecotypes were under 10\% (Table 3). However, based on values of RSR and NSE, both upland and lowland simulations may be evaluated as "satisfactory" according to Moriasi et al. [84]. As the model validation results, regression analysis for simulated and measured yields of lowland and upland cultivars, including all data from total 59 study sites, revealed $\mathrm{R}^{2}=0.65$ (Figure 4 and Table 3). The upland ecotype yield simulation had a lower RMSE (2.36 Mg ha $\left.{ }^{-1}\right)$ than the lowland simulation $\left(\right.$ RMSE $=3.74 \mathrm{Mg} \mathrm{ha}^{-1}$ ).


Figure 4. Results of model validation: relation between measured and ALMANAC simulated yields for lowland and upland switchgrass cultivars. The measured yields were averaged across cultivars within each ecotype from each study location. The solid line is the fitted regression line and the dash line is the 1:1 line.

\subsection{Switchgrass Yields in the Reference Period}

The switchgrass yields in two different nitrogen treatments (N50 and N150) for each study area were estimated for the reference period (1976-2005) using the validated ALMANAC model, as shown in Figure 5. According to ARM regression analysis, the switchgrass yields were significantly related to longitude in study sites (Equations (8) and (9)). The ALMANAC simulated yields were highly related to longitude when lowland and upland cultivars were treated by N50 and N150, respectively (Figure 5). The yields of lowland and upland cultivars appeared to decline from 80 to $100^{\circ} \mathrm{W}$ under N50 and N150 treatments, respectively (Figure 5). Many of the observations were made between 90 and $100^{\circ} \mathrm{W}$, so both high and low yield values were observed in that regions. The simulated yields of lowland cultivars with higher nitrogen treatment were not related to the longitude. The lowland cultivars tended to have average yields of $11.72 \mathrm{Mg} \mathrm{ha}^{-1}$ consistently across locations. The yields of upland cultivars with low nitrogen treatment were not related to the longitude; they appeared to remain consistent around $5.53 \mathrm{Mg} \mathrm{ha}^{-1}$ across locations. According to ALMANAC simulation results, switchgrass yield's response to longitude varied by crop management, which means that the management may be a more important determinant yield factor than longitude.

\subsection{Switchgrass Yields in the Future Climate}

Comparing historical-observed (1976-2005) and future period (2021-2050) total precipitation (April-September), maximum temperature(Tmax), and minimum temperature (Tmin) values across the study areas, on average, the total precipitation, Tmax, and Tmin values increase from current period to future period in both RCP scenarios (Figure S2). Maximum temperature values in future period increased by 2.22 and $2.52{ }^{\circ} \mathrm{C}$ on average across study locations, years, and GCMs under the RCP 4.5 and 8.5 pathways, respectively. The minimum temperature values in future period increased by 2.26 and $2.67{ }^{\circ} \mathrm{C}$ on average across study locations, years, and GCMs under the RCP 4.5 and 8.5 pathways, respectively. Unlike temperature, precipitation changes varied greatly across GCMs within each study area (Figure S3). In the future period, according to CESM1-CAM5 model, most parts of study areas will experience a significant increase in precipitation under both RCP4.5 and 8.5 pathways, while the HadGEM2-CC model expected that precipitation will mostly decrease across locations (Figure S3). 



Figure 5. ALMANAC simulated yields for lowland and upland switchgrass cultivars in two different nitrogen (N) fertilizer treatments, N50 and N150 kg ha ${ }^{-1}$. The simulated yields were averaged over the reference period (1976-2005) from each study location. The grey solid line is the fitted regression line.

Switchgrass is $\mathrm{C}_{4}$ warm season grass, and therefore an increase in temperature can, in theory, increase its yield in the absence of drought limitations. However, the results show that two switchgrass ecotypes show different yield patterns in the future period (Figure 6). In the future period, lowland switchgrass yields tended to increase in the areas located between longitude -85 and -80 degrees under high and low nitrogen treatments in both RCP 4.5 and 8.5 pathways. In these study areas, increased temperature may increase the duration of switchgrass growth (according to maximum heat unit approach), which may increase vegetative development (node and leaf appearance rate). However, lowland switchgrass yield variation across GCMs within each study area was becoming greater in RCP 8.5 pathway. As shown in Figure S3, RCP 8.5 pathway showed higher means of the daily maximum and minimum temperatures than RCP 4.5 scenarios. These warmer temperatures may limit switchgrass production increases achieved through the high nitrogen application across all study regions. Under high nitrogen treatment, for example, the lowland switchgrass yield differences between the least predicted yield and the greatest predicted yield among eight GCMs within each study area were between 1.7 and $8.7 \mathrm{Mg} \mathrm{ha}^{-1}$. Yield simulations based on MIROC5 produced nearly half the yields predicted based on other GCMs in areas located between longitude -101 to -93 degrees. According to MIROC5 model, maximum temperatures will mostly increase about $3.4^{\circ} \mathrm{C}$, which is higher than temperature predicted by other models (Figure S3). The total precipitation will vary between study areas, but several areas will experience a decrease, or little change in precipitation (Figure S3). The increase in temperature can cause faster heat unit accumulation; that can lead to shorter duration of growth and increased heat stress.

In comparison with lowland cultivars, yield changes were barely observed for upland cultivars under both high and low nitrogen treatments under RCP 4.5 and 8.5 pathways. Yield variation across GCMs within each study area was much smaller than lowland cultivars. However, yield patterns for upland cultivars vary under different nitrogen treatments. Under high nitrogen treatment, small yield variations for upland cultivars across GCM were observed between longitude -102 and -97 degrees, while yield variations were observed between -89 and -83 degrees under low nitrogen treatments. This may be related to the potential heat units. As temperature increases under RCP 4.5 and 8.5 pathways, in simulation, the maximum potential heat units of upland ecotypes may be reached earlier, which prevents their growth. Due to this early maturity, upland ecotypes may not respond to the fertilizer application in most study locations. 
Lowland N50,RCP4.5

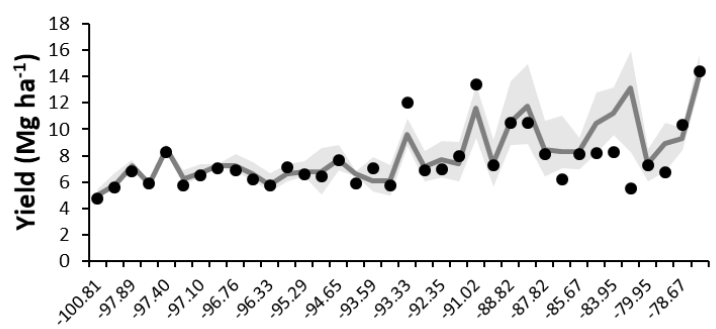

Study site longitude $\left({ }^{\circ}\right)$

Lowland N50, RCP8.5



Study site longitude $\left({ }^{\circ}\right)$

Upland N50, RCP4.5
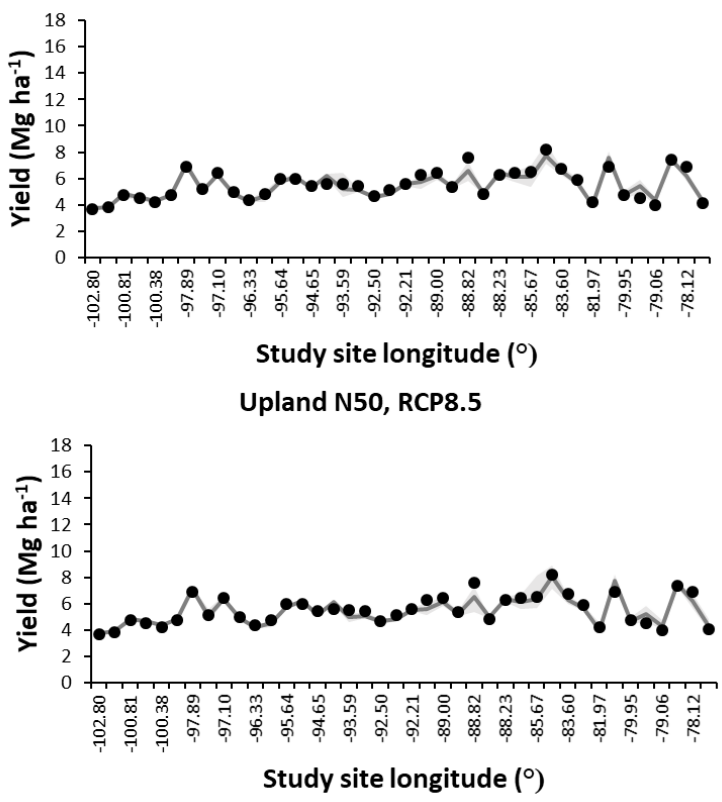

Lowland N150, RCP4.5



Lowland N150, RCP8.5

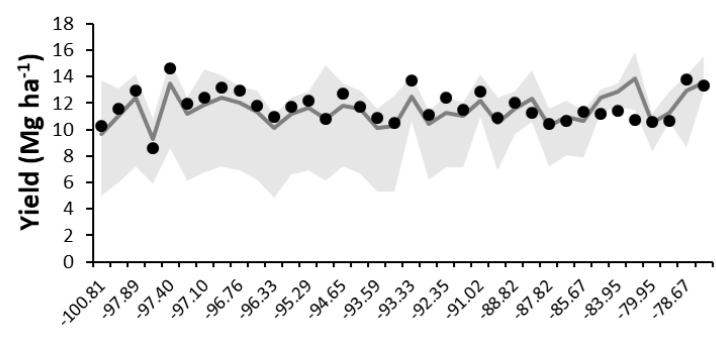

Study site longitude $\left({ }^{\circ}\right)$

Upland N150, RCP4.5
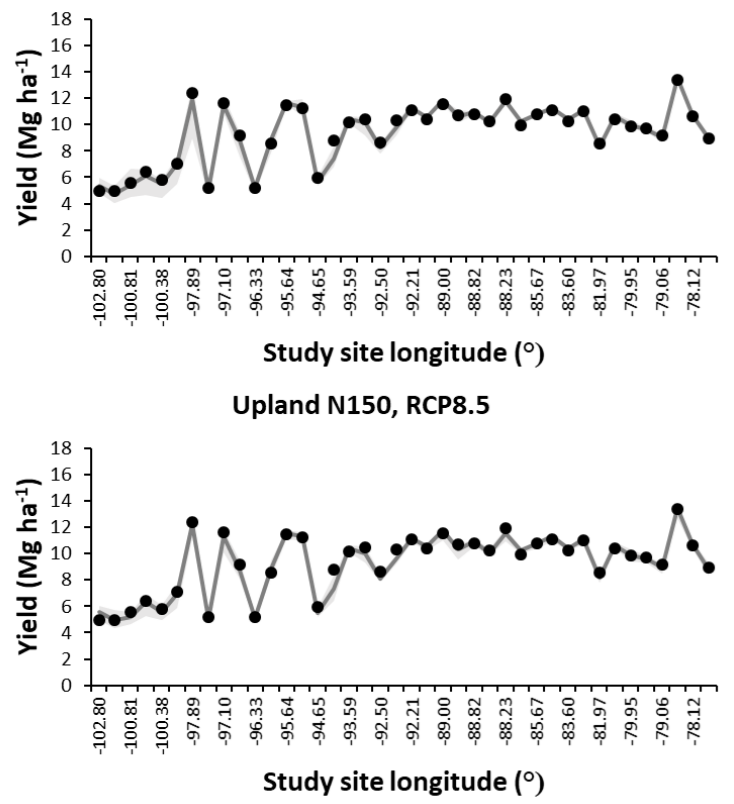

Figure 6. Impact of climate change on yields of switchgrass lowland and upland cultivars in two different nitrogen $(\mathrm{N})$ fertilizer treatments, $\mathrm{N} 50$ and $\mathrm{N} 150 \mathrm{~kg} \mathrm{ha}^{-1}$. The switchgrass simulation yields in the future period (2021-2050) across study areas for each nitrogen treatment within each ecotype and within each RCP pathway were compared with the reference period (1976-2005) period. Grey shade areas indicate the range of simulation yields in future period based on running eight global circulation models (GCMs). The dark grey line showed average simulation yields in the future period based on running eight GCMs. Black circle indicates simulation yields in reference period.

\section{Conclusions}

This study analyzed switchgrass productivity data from multiple sites across the U.S. Each observation has been identified by cultivar, ecotype, stand age, harvest system, $\mathrm{N}$ application rate, planting location, soil, and year of harvest. The additive regression model, ARM, was developed based on few key parameters (e.g., climate, fertilizer, and location) and used to evaluate relationship among 
the key parameters and yield through analyzing past growth data. According to ARM simulation results, the yields of switchgrass lowland upland cultivars were highly related to longitude of the study location. This result was used for analysis of ALMANAC climate change simulation results. The collected yield data was used to develop a process-based model and to improve switchgrass yield simulation accuracy. ALMANAC model simulates key physiological processes linking weather to plant yield production. Many of the essential parameters in the model have been established through experiments or literature reviews. As a result, the ALMANAC model can predict switchgrass yield relatively well for both switchgrass cultivars. For climate change simulations, the validated ALMANAC was used to quantify the climate change impacts on switchgrass yields. Based on the simulation results in reference period (1976-2005), overall, switchgrass yield response to longitude varied according to nitrogen application rates. For example, yields of switchgrass lowland cultivar responded well to variation in longitude with low nutrient application, while upland cultivars appeared to suffer from a nutrient deficiency across locations. Under high nutrient application rates, upland cultivars appeared to relate to longitude and had greater dry yield at the more eastern locations. The validated ALMANAC model was used to quantify the impact of climate change on switchgrass yield with two different nitrogen fertilizer applications. In the future period (2021-2050), both RCP4.5 and 8.5 of eight climate models showed an increase of temperature across study locations. Changes in precipitation differed across GCMs and locations. According to CESM1-CAM5 model, most areas will experience an increase in precipitation, while the HadGEM2-CC model tends to have a decrease in precipitation. ALMANAC simulated yields of lowland cultivars are projected to increase in areas located in longitude between -88 and -80 degrees under high and low nitrogen treatments in both RCP 4.5 and 8.5 pathways. Under RCP 8.5 pathway, the simulation results for lowland cultivars show substantial variation across GCMs. One of the GCMs, MIROC5, predicted nearly half size of yields that were simulated based on other GCMs across each study area located between longitude -101 to -93 degrees. Unlike lowland cultivars, climate variability barely affected production of upland cultivars. On the basis of the overall simulation results, yields of lowland and upland switchgrass increased with increasing nitrogen application. However, lowland and upland ecotypes responded differently to climate variability. While upland cultivars appeared to be showing no responses from climate change, the warmer temperatures may limit productions of lowland cultivars even though high nitrogen was applied to the plots. This paper shows that the fertilizer management may be the most important factor for upland cultivars, which will control switchgrass yield under increasing temperature. This finding will be useful for overcoming the impacts of climate change on switchgrass yield and make switchgrass more adapted and perform better in a wide range of locations in the U.S.

Supplementary Materials: The following are available online at http://www.mdpi.com/2073-4395/10/4/503/s1, Table S1: Study locations (states), switchgrass ecotype (L: Lowland, U: Upland), cultivars, minimum and maximum biomass dry yield $\left(\mathrm{Mg} \mathrm{ha}^{-1}\right)$, and references. Table S2. Summary of soil characteristics $(0-30 \mathrm{~cm} \mathrm{depth})$ measured for switchgrass production studies conducted in Ohio, Kansas, and Oklahoma, USA. SOC indicates soil organic carbon in soil; TN indicates total nitrogen in soil. Table S3. Key ALMANAC plant parameters for switchgrass lowland and upland ecotypes. Figure S1: Biomass yields for lowland and upland cultivars of switchgrass. Grey bar indicates the mean yield value for each cultivar. Upper bar indicates standard deviation for each cultivar. Number above cap of bar indicates the number of observations for each cultivar. Figure S2: Changes in mean total precipitation (April-September), Tmax, and Tmin for the reference period (1976-2005) compared to and two RCP scenarios (RCP4.5 and RCP8.5) in the future period (2021-2050) across study areas. Empty circle, RCP4.5, mean value of eight GCMs in the future period (2021-2050). Dark circle, RCP8.5, mean value of eight GCMs in the future period (2021-2050). Figure S3: Changes of total precipitation (April-September, mm), and maximum and minimum temperatures $\left({ }^{\circ} \mathrm{C}\right)$ of the future period (2021-2050) as simulated by eight climate models under RCP4.5 and 8.5 pathways from the reference period (1976-2005) across all study areas. Values in control rows show the total precipitation and maximum and minimum temperatures in the reference period (1976-2005).

Author Contributions: Conceptualization, S.K. (Sumin Kim); methodology, S.K. (Sumin Kim), S.K. (Sojung Kim), J.C., and J.R.K.; software, S.K. (Sumin Kim), S.K. (Sojung Kim), and J.C.; validation, S.K. (Sumin Kim); formal analysis, S.K. (Sumin Kim); investigation, S.K. (Sumin Kim); data mining, S.P. and F.X.J.P.; writing-original draft preparation, S.K. (Sumin Kim); writing—review and editing, S.P., J.R.K., and S.K. (Sumin Kim); funding acquisition, J.R.K. All authors have read and agreed to the published version of the manuscript. 
Funding: This work was also supported in part by an appointment to the Agricultural Research Service administered by the Oak Ridge Institute for Science and Education through interagency agreement between the U.S. Department of Energy (DOE) and the U.S. Department of Agriculture (USDA), Agricultural Research Service Agreement \#60-3098-5-002.

Acknowledgments: We are grateful to Jaehak Jeong and Haw Yen for their valuable support of this research.

Conflicts of Interest: The authors declare no conflict of interest.

\section{References}

1. EIA, Monthly Energy Review. U.S. Energy Information Admistration; EIA: Washington, DC, USA, 2017.

2. Gomiero, T. Are Biofuels an Effective and Viable Energy Strategy for Industrialized Societies? A Reason. Overv. Potentials Limits 2015, 7, 8491-8521.

3. Owusu, P.A.; Asumadu-Sarkodie, S. A review of renewable energy sources, sustainability issues and climate change mitigation. Cogent Eng. 2016, 3, 1167990. [CrossRef]

4. Worldwatch. Biofuels for Transportation; Worldwatch Institute: Washington, DC, USA, 2006.

5. EPA. Inventory of U.S. Greenhouse Gas Emissions and Sinks: 1990-2015; U.S. Envrionmental Protection Agency: Washington, DC, USA, 2017.

6. GPO. Public Law 110-140: The Energy Independence and Security Act of 2007 (EISA); U.S. Government Printing Office: Washington, DC, USA, 2007.

7. EIA. Almost All U.S. Gasoline is Blended with 10\% Ethanol; U.S. Energy Information Admistration: Washington, DC, USA, 2016.

8. Foley, J. It's Time to Rethink America's Corn System. Scientific American. Available online: https://www. scientificamerican.com/article/time-to-rethink-corn/ (accessed on 24 January 2018).

9. Duffield, J.A.; Xiarchos, I. Effects of policy on ethanol industry growth. In U.S. Ethanol: An Examination of Policy, Production, Use, Distribution, and Market Interactions; Duffield, J.A., Johansson, R., Meyer, S., Eds.; USDA: Washington, DC, USA, 2015.

10. Statista. Global Biofuel Production by Select Country 2016; Statista: New York, NY, USA, 2018.

11. Siciliano, J. Corn Ethanol Faces Its Limits under EPA Fuel Mandate; Washington Examiner: Washington, DC, USA, 2017.

12. Prentice, C.; Renshaw, J.; Shepardson, D.U.S. Proposes Cutting Total Biofuels Requirements in 2018; 2017. REUTERS. Available online: https://www.reuters.com/article/us-usa-biofuels/u-s-proposes-cutting-totalbiofuels-requirements-in-2018-idUSKBN19Q27M (accessed on 25 January 2018).

13. Youngs, H.; Somerville, C. Development of feedstocks for cellulosic biofuels. F1000 Boil. Rep. 2012, 4, 10. [CrossRef] [PubMed]

14. Sanderson, M.; Adler, P.; Boateng, A.; Casler, M.D.; Sarath, G. Switchgrass as a biofuels feedstock in the USA. Can. J. Plant Sci. 2006, 86, 1315-1325. [CrossRef]

15. Mitchell, R.; Vogel, K.P.; Sarath, G. Managing and enhancing switchgrass as a bioenergy feedstock. Biorefining 2008, 2, 530-539. [CrossRef]

16. Mehmood, M.; Rashid, U.; Nawaz, M.; Ali, S.; Hussain, A.; Gull, M. Biomass production for bioenergy using marginal lands. Sustain. Prod. Consum. 2017, 9, 3-21. [CrossRef]

17. Quinn, L.D.; Straker, K.C.; Guo, J.; Kim, S.; Thapa, S.; Kling, G.; Lee, D.K.; Voigt, T.B. Stress-Tolerant Feedstocks for Sustainable Bioenergy Production on Marginal Land. BioEnergy Res. 2015, 8, 1081-1100. [CrossRef]

18. Antizar-Ladislao, B.; Turrion-Gomez, J.L. Second-generation biofuels and local bioenergy systems. Biofuels, Bioprod. Biorefining 2008, 2, 455-469. [CrossRef]

19. EIA. Monthly Biodiesel Production Report; U.S. Energy Information Admistration: Washington, DC, USA, 2017.

20. Lynd, L.R.; Liang, X.; Biddy, M.J.; Allee, A.; Cai, H.; Foust, T.; Himmel, M.E.; Laser, M.S.; Wang, M.; Wyman, C.E. Cellulosic ethanol: Status and innovation. Curr. Opin. Biotechnol. 2017, 45, 202-211. [CrossRef]

21. Brechbill, S.C.; Tyner, W.E. The Economics of Biomass Collection, Transportation, and Supply to Indiana Cellulosic and Electric Utility Facilities; Purdue University Press: Purdue, IN, USA, 2008.

22. Lin, T.; Rodríguez, L.F.; Davis, S.; Khanna, M.; Shastri, Y.; Grift, T.; Long, S.; Ting, K.C. Biomass feedstock preprocessing and long-distance transportation logistics. GCB Bioenergy 2016, 8, 160-170. [CrossRef] 
23. TCS. Federal Subsidies for Corn Ethanol and Other Corn-Based Biofuels; Taxpayers for Common Sense: Mumbai, India, 2018.

24. EPA. Final Renewable Fuel Standards for 2017, and the Biomass-Based Diesel Volume for 2018; U.S. Environmental Protection Agency: Washington, DC, USA, 2018.

25. Brown, T.R. Why the cellulosic biofuels mandate fell short: A markets and policy perspective. Biofuels Bioprod. Biorefining 2019, 13, 889-898. [CrossRef]

26. Meyer, S.; Thompson, W. How Do Biofuel Use Mandates Cause Uncertainty? United States Environmental Protection Agency Cellulosic Waiver Options. Appl. Econ. Perspect. Policy 2012, 34, 570-586. [CrossRef]

27. Reichmann, L.; Collins, H.; Jin, V.; Johnson, M.-V.; Kiniry, J.; Mitchell, R.; Polley, H.; Fay, P. Inter-Annual Precipitation Variability Decreases Switchgrass Productivity from Arid to Mesic Environments. BioEnergy Res. 2018, 11, 614-622. [CrossRef]

28. Lee, J.; Pedroso, G.; Linquist, B.A.; Putnam, D.; van Kessel, C.; Six, J. Simulating switchgrass biomass production across ecoregions using the DAYCENT model. GCB Bioenergy 2012, 4, 521-533. [CrossRef]

29. Behrman, K.D.; Keitt, T.H.; Kiniry, J.R. Modeling Differential Growth in Switchgrass Cultivars across the Central and Southern Great Plains. BioEnergy Res. 2014, 7, 1165-1173. [CrossRef]

30. Smith, P.; Clark, H.; Dong, H.; Elsiddig, E.A.; Haberl, H.; Harper, R.; House, J.; Jafari, M.; Masera, O.; Mbow, C.; et al. Agriculture, forestry and other land use (AFOLU). In Climate Change 2014: Mitigation of Climate Change. In Working Group III to the Fifth Assessment Report of the Intergovernmental Panel on Climate Change; Edenhofer, O.R.P.-M., Sokona, Y., Farahani, E., Kadner, S.S.K., Adler, A., Baum, I., Brunner, S., Eickemeier, P., Eds.; Cambridge University Press: Cambridge, UK, 2014.

31. Graves, R.A.; Pearson, S.M.; Turner, M.G. Landscape patterns of bioenergy in a changing climate: Implications for crop allocation and land-use competition. Ecol. Appl. 2016, 26, 515-529. [CrossRef]

32. Liu, L.; Basso, B. Spatial evaluation of switchgrass productivity under historical and future climate scenarios in Michigan. GCB Bioenergy 2017, 9, 1320-1332. [CrossRef]

33. Smith, P.; Smith, J.U.; Powlson, D.S.; Mcgill, W.B.; Arah, J.R.M.; Chertov, O.G.; Coleman, K.; Franko, U.; Frolking, S.; Jenkinson, D.S.; et al. A comparison of the performance of nine soil organic matter models using datasets from seven long-term experiments. Geoderma 1997, 81, 153-225. [CrossRef]

34. Williams, J.R.; Arnold, J.G.; Kiniry, J.R.; Gassman, P.W.; Green, C.H. History of model development at Temple, Texas. Hydrol. Sci. J. 2008, 53, 948-960. [CrossRef]

35. Meki, M.N.; Snider, J.L.; Kiniry, J.R.; Raper, R.L.; Rocateli, A.C. Energy sorghum biomass harvest thresholds and tillage effects on soil organic carbon and bulk density. Ind. Crops Products 2013, 43, 172-182. [CrossRef]

36. Kiniry, J.R.; Cassida, K.A.; Hussey, M.A.; Muir, J.P.; Ocumpaugh, W.R.; Read, J.C.; Reed, R.L.; Sanderson, M.A.; Venuto, B.C.; Williams, J.R. Switchgrass simulation by the ALMANAC model at diverse sites in the southern US. Biomass Bioenergy 2005, 29, 419-425. [CrossRef]

37. Kim, S.; Kiniry, J.R.; Williams, A.S.; Meki, N.; Gaston, L.; Brakie, M.; Shadow, A.; Fritschi, F.B.; Wu, Y. Adaptation of C4 Bioenergy Crop Species to Various Environments within the Southern Great Plains of USA. Sustainability 2017, 9, 89. [CrossRef]

38. McMillan, C. The role of ecotypic variation in the distribution of the central grassland of North America. Ecol. Monogr. 1959, 29, 285-308. [CrossRef]

39. Zhang, Y.; Zalapa, J.E.; Jakubowski, A.R.; Price, D.L.; Acharya, A.; Wei, Y.; Brummer, E.C.; Kaeppler, S.M.; Casler, M.D. Post-glacial evolution of Panicum virgatum: Centers of diversity and gene pools revealed by SSR markers and cpDNA sequences. Genetica 2011, 139, 933-948. [CrossRef]

40. Milano, E.; Lowry, D.; Juenger, T. The Genetic Basis of Upland/Lowland Ecotype Divergence in Switchgrass (Panicum virgatum). G3 (Bethesda Md.) 2016, 6, 3561-3570. [CrossRef]

41. Cassida, K.; Kirkpatrick, T.L.; Robbins, R.T.; Muir, J.; Venuto, B.C.; Hussey, M.A. Plant-parasitic nematodes associated with switchgrass (Panicum virgatum L.) grown for biofuel in the South Central United States. Nematropica 2005, 35, 1-10.

42. Parrish, D.; Samson, R. Establishing and Managing Switchgrass as an Energy Crop. In Forage and Grazinglands; Plant Management Network: St. Paul, MI, USA, 2008.

43. NOAA. Climate Data Online Search; National Oceanic and Atmospheric Administration: Silver Spring, MA, USA, 2012.

44. NRCS-USDA. Web Soil Survey; U.S. Department of Agriculture, Natrual Resources Conservation Service: Washington, DC, USA, 2018. 
45. Kandel, T.P.; Wu, Y.; Kakani, V.G. Growth and Yield Responses of Switchgrass Ecotypes to Temperature. Am. J. Plant Sci. 2013, 4, 8. [CrossRef]

46. Hui, D.; Yu, C.-L.; Deng, Q.; Dzantor, E.K.; Zhou, S.; Dennis, S.; Sauve, R.; Johnson, T.L.; Fay, P.A.; Shen, W.; et al. Effects of precipitation changes on switchgrass photosynthesis, growth, and biomass: A mesocosm experiment. PLoS ONE 2018, 13, e0192555. [CrossRef]

47. McGowan, A.R.; Min, D.-H.; Williams, J.R.; Rice, C.W. Impact of Nitrogen Application Rate on Switchgrass Yield, Production Costs, and Nitrous Oxide Emissions. J. Environ. Qual. 2018, 47, 228-237. [CrossRef]

48. de Koff, J.; Tyler, D. Improving Switchgrass Yields for Bioenergy Production. Coop Ext Fac. Res. 2012, 40, 1-5.

49. Kim, S.; Kim, S.; Kiniry, J.R. Two-phase simulation-based location-allocation optimization of biomass storage distribution. Simul. Model. Pract. Theory 2018, 86, 155-168. [CrossRef]

50. Rogers, S.; Girolami, M. A First Course in Machine Learning; CRC Press: Boca Raton, FL, USA, 2011.

51. Grassini, P.; van Bussel, L.G.J.; Wart, J.V.; Wolf, J.; Classens, L.; Yang, H.; Boogaard, H.; de Groot, H.; van Ittersum, M.K.; Cassman, K.G. How good is good enough? Data requirements for reliable crop yield simulations and yield-gap analysis. Field Crops Res. 2015, 177, 49-63. [CrossRef]

52. Jung, J.Y.; Lal, R. Impacts of nitrogen fertilization on biomass production of switchgrass (Panicum Virgatum L.) and changes in soil organic carbon in Ohio. Geoderma 2011, 166, 145-152. [CrossRef]

53. Propheter, J.L.; Staggenborg, S.A.; Wu, X.; Wang, D. Performance of Annual and Perennial Biofuel Crops: Yield during the First Two Years. Agron. J. 2010, 102, 806-814. [CrossRef]

54. Kering, M.K.; Biermacher, J.T.; Butler, T.J.; Mosali, J.; Guretzky, J.A. Biomass Yield and Nutrient Responses of Switchgrass to Phosphorus Application. BioEnergy Res. 2012, 5, 71-78. [CrossRef]

55. Casler, M.D. Ecotypic Variation among Switchgrass Populations from the Northern USA This research was funded in part by Specific Cooperative Agreement 58-5440-7-123 between the USDA-ARS and the University of Wisconsin-Madison, which was a component of the U.S. Department of Energy, Oak Ridge National Laboratory and USDA-ARS Interagency Agreement under contract DE-A105-900R21954. Crop Sci. 2005, 45, 388-398.

56. Cortese, L.M.; Honig, J.; Miller, C.; Bonos, S.A. Genetic Diversity of Twelve Switchgrass Populations Using Molecular and Morphological Markers. BioEnergy Res. 2010, 3, 262-271. [CrossRef]

57. Kiniry, J.R.; Lynd, L.; Greene, N.; Johson, M.-V.V.; Casler, M.; Laser, M.S. Biofuels and Water Use: Comparison of Maize and Switchgrass and General Perspectives. In New Research on Biofuels; Wright, J.H., Evans, D.A., Eds.; Nova Science Publisher, Inc.: Hapac, NY, USA, 2008.

58. Madakadze, I.C.; Coulman, B.E.; McElroy, A.R.; Stewart, K.A.; Smith, D.L. Evaluation of selected warm-season grasses for biomass production in areas with a short growing season. Bioresour. Technol. 1998, 65, 1-12. [CrossRef]

59. Heaton, E.A.; Dohleman, F.G.; Long, S.P. Meeting US biofuel goals with less land: The potential of Miscanthus. Glob. Chang. Biol. 2008, 14, 2000-2014. [CrossRef]

60. Kiniry, J.R.; Sanderson, M.A.; Williams, J.R.; Tischler, C.R.; Hussey, M.A.; Ocumpaugh, W.R.; Read, J.C.; Van Esbroeck, G.; Reed, R.L. Simulating Alamo Switchgrass with the ALMANAC Model. Agron. J. 1996, 88, 602-606. [CrossRef]

61. Kiniry, J.; Johnson, M.-V.; Mitchell, R.; Vogel, K.; Kaiser, J.; Bruckerhoff, S.; Cordsiemon, R. Switchgrass Leaf Area Index and Light Extinction Coefficients. Agron. J. 2011, 103, 119. [CrossRef]

62. Kiniry, J.R.; Anderson, L.C.; Johnson, M.-V.V.; Behrman, K.D.; Brakie, M.; Burner, D.; Cordsiemon, R.L.; Fay, P.A.; Fritschi, F.B.; Houx, J.H.; et al. Perennial Biomass Grasses and the Mason-Dixon Line: Comparative Productivity across Latitudes in the Southern Great Plains. BioEnergy Res. 2013, 6, 276-291. [CrossRef]

63. Tubeileh, A.; Rennie, T.; Kerr, A.; Saita, A.; Patanè, C. Biomass Production by Warm-Season Grasses as Affected by Nitrogen Application in Ontario. Agron. J. 2014, 106, 416-422. [CrossRef]

64. Gent, P.R.; Danabasoglu, G.; Donner, L.J.; Holland, M.M.; Hunke, E.C.; Jayne, S.R.; Lawrence, D.M.; Neale, R.B.; Rasch, P.J.; Vertenstein, M.; et al. The Community Climate System Model Version 4. J. Clim. 2011, 24, 4973-4991. [CrossRef]

65. Meehl, G.A.; Washington, W.M.; Arblaster, J.M.; Hu, A.; Teng, H.; Kay, J.E.; Gettelman, A.; Lawrence, D.M.; Sanderson, B.M.; Strand, W.G. Climate Change Projections in CESM1(CAM5) Compared to CCSM4. J. Clim. 2013, 26, 6287-6308. [CrossRef]

66. Fogli, P.G.; Manzini, E.; Vichi, M.; Alessandri, A.; Patara, L.; Gualdi, S.; Scoccimarro, E.; Masina, S.; Navarra, A. INGV-CMCC Carbon (ICC): A carbon cycle Earth system model. SSRN Electron. J. 2009. [CrossRef] 
67. Dunne, J.P.; John, J.G.; Shevliakova, E.; Stouffer, R.J.; Krasting, J.P.; Malyshev, S.L.; Milly, P.C.D.; Sentman, L.T.; Adcroft, A.J.; Cooke, W.; et al. GFDL's ESM2 Global Coupled Climate-Carbon Earth System Models. Part II: Carbon System Formulation and Baseline Simulation Characteristics. J. Clim. 2013, 26, 2247-2267. [CrossRef]

68. Baek, H.-J.; Lee, J.; Lee, H.-S.; Hyun, Y.-K.; Cho, C.; Kwon, W.-T.; Marzin, C.; Gan, S.-Y.; Kim, M.-J.; Choi, D.-H.; et al. Climate change in the 21st century simulated by HadGEM2-AO under representative concentration pathways. Asia-Pacific J. Atmos. Sci. 2013, 49, 603-618. [CrossRef]

69. Watanabe, M.; Suzuki, T.; O'ishi, R.; Komuro, Y.; Watanabe, S.; Emori, S.; Takemura, T.; Chikira, M.; Ogura, T.; Sekiguchi, M.; et al. Improved Climate Simulation by MIROC5: Mean States, Variability, and Climate Sensitivity. J. Clim. 2010, 23, 6312-6335. [CrossRef]

70. Giorgetta, M.A.; Jungclaus, J.; Reick, C.H.; Legutke, S.; Bader, J.; Böttinger, M.; Brovkin, V.; Crueger, T.; Esch, M.; Fieg, K.; et al. Climate and carbon cycle changes from 1850 to 2100 in MPI-ESM simulations for the Coupled Model Intercomparison Project phase 5. J. Adv. Model. Earth Syst. 2013, 5, 572-597. [CrossRef]

71. Kitoh, A.; Noda, A.; Nikaidou, Y.; Ose, T.; Tokioka, T. AMIP Simulations of the MRl GCM. Papers Meteorol. Geophys. 1995, 45, 121-148. [CrossRef]

72. Cho, J.; Ko, G.; Kim, K.; Oh, C. Climate Change Impacts on Agricultural Drought with Consideration of Uncertainty in CMIP5 Scenarios. Irrig. Drain. 2016, 65, 7-15. [CrossRef]

73. Li, Y.; Miao, R.; Khanna, M. Effects of Ethanol Plant Proximity and Crop Prices on Land-Use Change in the United States. Am. J. Agric. Econ. 2018, 101, 467-491. [CrossRef]

74. Sladden, S.E.; Bransby, D.I.; Aiken, G.E. Biomass yield, composition and production costs for eight switchgrass varieties in Alabama. Biomass Bioenergy 1991, 1, 119-122. [CrossRef]

75. Kiniry, J.R.; Tischler, C.R.; Van Esbroech, G.A. Radiation use efficiency and leaf CO2 exchange for diverse C4 grasses. Biomass Bioenergy 1999, 17, 95-112. [CrossRef]

76. Marra, M.; Keene, T.; Skousen, J.; Griggs, T. Switchgrass Yield on Reclaimed Surface Mines for Bioenergy Production. J. Environ. Qual. 2013, 42, 696-703. [CrossRef]

77. Casler, M.D.; Vogel, K.; Taliaferro, C.M.; Ehlke, N.; Berdahl, J.D.; Brummer, C.; Kallenbach, R.L.; West, C.P.; Mitchell, R. Latitudinal and Longitudinal Adaptation of Switchgrass Populations. Crop Sci. 2007, 47. [CrossRef]

78. Sanderson, M.; Read, J.; Reed, R. Harvest Management of Switchgrass for Biomass Feedstock and Forage Production. Agron. J. AGRON J. 1999, 91, 5-10. [CrossRef]

79. Casler, M.; Boe, A.R. Cultivar $\times$ Environment Interactions in Switchgrass. Crop Science CROP SCI 2003, 43, 2226-2233. [CrossRef]

80. Davis, E.B.; Jager, H.J.; West, T.O.; Perlack, R.D.; Brandt, C.C.; Wullschleger, S.D.; Baskaran, L.M.; Wilkerson, E.G.; Downing, M.E.; Gunderson, C.A. Exploring Potential U.S. Switchgrass Production for Lignocellulosic Ethanol; US Department Energy Publication: Washington, DC, USA, 2008; Volume 16, pp. 1-45.

81. Abdullahi, A.A.; Aliero, B.L.; Aliero, A.A.; Zuru, A.A. Effects of Irrigation Regime, Organic and Inorganic Mineral Source on Growth and Yield Components of Switchgrass (Panicum virgatum L.) in Upland and Lowland Conditions in Sokoto, Nigeria. Pak. J. Biol. Sci. PJBS 2013, 16, 51-58.

82. Sanderson, M.; Reed, R. Switchgrass Growth and Development: Water, Nitrogen, and Plant Density Effects. J. Range Manag. 2000, 53, 221-227. [CrossRef]

83. Fike, J.H.; Pease, J.W.; Owens, V.N.; Farris, R.L.; Hansen, J.L.; Heaton, E.A.; Hong, C.O.; Mayton, H.S.; Mitchell, R.B.; Viands, D.R. Switchgrass nitrogen response and estimated production costs on diverse sites. GCB 2017, 9, 1526-1542. [CrossRef]

84. Moriasi, D.; Arnold, J.; Van Liew, M.; Bingner, R.; Harmel, R.D.; Veith, T. Model Evaluation Guidelines for Systematic Quantification of Accuracy in Watershed Simulations. Transactions of the ASABE 2007, 50, 885-900. [CrossRef]

(C) 2020 by the authors. Licensee MDPI, Basel, Switzerland. This article is an open access article distributed under the terms and conditions of the Creative Commons Attribution (CC BY) license (http://creativecommons.org/licenses/by/4.0/). 